\title{
Fe-RICH PRECIPITATES IN TWIN-ROLL CAST 8006 ALUMINUM ALLOY AND THEIR EVOLUTION DURING HIGH TEMPERATURE ANNEALING
}

\author{
Rostislav KRÁLíK, Michal HÁJEK, Barbora KŘIVSKÁ, BAJTOŠOVÁ, Jan BAJER, \\ Miroslav CIESLAR
}

Charles University, Faculty of Mathematics and Physics, Prague, Czech Republic, EU

rkralik96@gmail.com

https://doi.org/10.37904/metal.2019.947

\begin{abstract}
Iron is present in nearly all aluminum alloys as an impurity causing a formation of iron-rich precipitates in the as-cast state of the alloy due to its low solubility in the matrix. Dispersion, morphology and relative coarseness of precipitates may affect formation of unwanted pinholes during cold rolling to thin gauges. When used as foil stock these pinholes may negatively affect utility of the foil. Heat treatment may be employed during downstream processing to influence distribution of the precipitates. An impact of a high temperature annealing on iron-rich precipitates in a twin-roll cast EN-AW 8006 alloy was investigated. Electrical resistivity measurements with a heating rate simulating industrial annealing was performed to determine phase transformation temperatures. In-situ electron microscopy annealing was employed to directly observe mictrostructural transformations in the selected temperature intervals.
\end{abstract}

Keywords: Aluminum alloy, twin-roll casting, electron microscopy, annealing, resistometry.

\section{INTRODUCTION}

Several properties make aluminum a good candidate usable as a foil stock [1]. Fe and Si are the most common impurities present in aluminum ores and therefore they can be found in a wide variety of commercially available alloys. In the AlFeSi ternary system a considerable volume fraction of $\mathrm{Fe}$-rich precipitates forms due to a low solubility of iron in aluminum. Adding manganese to these alloys improves some of their properties such as corrosion resistance [2]. Many studies have been devoted to the effect of $\mathrm{Mn}$ on AlFeSi intermetallics showing that $\mathrm{Mn}$ substitutes $\mathrm{Fe}$ in these intermetallics and potentially alters their structure and morphology, mainly in the case of the $\alpha$-AlFeMnSi phase having the potential to be simple cubic, centered cubic or hexagonal depending on the $\mathrm{Mn}$ content [3-5]. Other phases such as $\mathrm{Al}_{13} \mathrm{Fe}_{4}, \mathrm{Al}_{4} \mathrm{Mn}$ and other metastable phases with varying stoichiometry may be present depending on the manufacturing method and processing [6]. The particles often have the so called Chinese script or platelet stoichiometry $[7,8]$.

Twin-roll casting is an energy saving method used often for the preparation of AlFeSi strips. Significant effort was put into optimizing the casting parameters to facilitate casting of commercially acceptable quality strips [911]. The main benefit compared to die casting or direct chill casting is a reduction of the number of steps during the downstream processing. A matrix supersaturation is much higher than in materials manufactured by traditional casting methods due to a high solidification rate [12]. Homogenization annealing is usually performed before further processing which consists of rolling to a gauge of 200-260 $\mu \mathrm{m}$ and then rolling to the desired foil gauge of about $10 \mu \mathrm{m}$. Certain morphologies, sizes and distributions of intermetallics may cause a formation of pinholes in the material during rolling to very thin gauges, which is generally undesirable [13]. It is of technological interest to perform homogenization annealing at a temperature at which the size and distribution of intermetallics is favorable towards reduction of pinhole formation.

AlFeMnSi alloy of the 8006 type prepared by TRC was studied. Resistivity measurements were used for the determination of temperature intervals with significant solute redistributions. In-situ transmission electron microscopy (TEM) mapping of phase transformations was performed in the intervals. 


\section{EXPERIMENTAL PROCEDURES}

An industrial twin-roll cast AIFeMnSi strip containing $1.289 \mathrm{wt} \% \mathrm{Fe}, 0.391 \mathrm{wt} \% \mathrm{Mn}$ and $0.034 \mathrm{wt} \% \mathrm{Si}$ was used in the study. TEM samples for in-situ TEM observations were prepared by an electrolytic polishing in a $20 \%$ solution of $\mathrm{HNO}_{3}$ in methanol at $-20{ }^{\circ} \mathrm{C}$. The subsequent annealing was performed in-situ using the JEOL FX2000 TEM. The model annealing was performed isochronaly with a $5^{\circ} \mathrm{C} / \mathrm{min}$ step up to $550{ }^{\circ} \mathrm{C}$ using a heating holder with a R-type thermocouple.

Electrical resistance measurements were performed in a linear heating mode up to $600{ }^{\circ} \mathrm{C}$ with a heating step of $1{ }^{\circ} \mathrm{C} / \mathrm{min}$ followed by cooling with the same rate. A four-point $\mathrm{DC}$ method on a device equipped with Keithley $2182 \mathrm{~A}$ nanovoltmeter was employed for the measurements of voltage and current with a relative error of resistance measurements lower than $0.01 \%$.

\section{RESULTS AND DISCUSSION}

\subsection{Resistometry measurements}

Resistivity measurements were made in order to establish proper intervals for a model in-situ TEM annealing. The resulting evolution of resistivity with temperature is non-trivial (Figure 1) and contains local maxima and minima appearing as a result of deviations from the Mathiessen rule [14]. As follows from the cooling run all processes occurring during heating are irreversible.

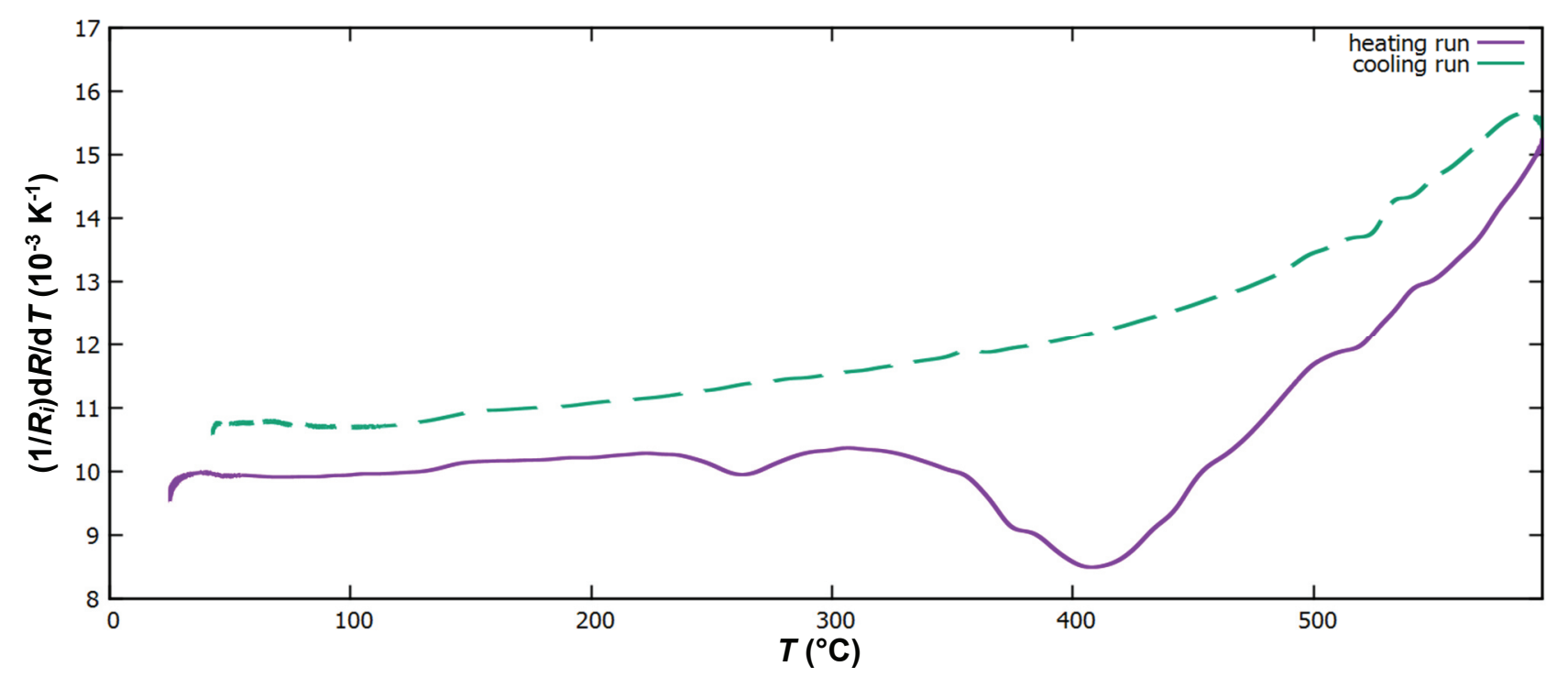

Figure 1 Resistivity measurement curves of the 8006 alloy during heating and cooling. $R_{i}$ is the initial resistance at room temperature.

The very first local minimum at $270{ }^{\circ} \mathrm{C}$ was omitted because it is generally connected with a recovery of the dislocation substructure [15]. The series of minima above this temperature are more important and they imply various structural changes. Based on these observations a temperature interval from $300{ }^{\circ} \mathrm{C}$ to $600{ }^{\circ} \mathrm{C}$ was chosen for the in-situ TEM annealing.

\subsection{TEM annealing}

In the as-cast state large colonies of eutectic particles containing alloying elements were observed. These colonies form cells mostly along grain boundaries elongated in the casting direction (Figure 2). The particles 
have an elongated shape and length of about $1 \mu \mathrm{m}$. Dislocations form dislocation cells as a result of a plastic deformation at elevated temperatures during the casting/rolling process.

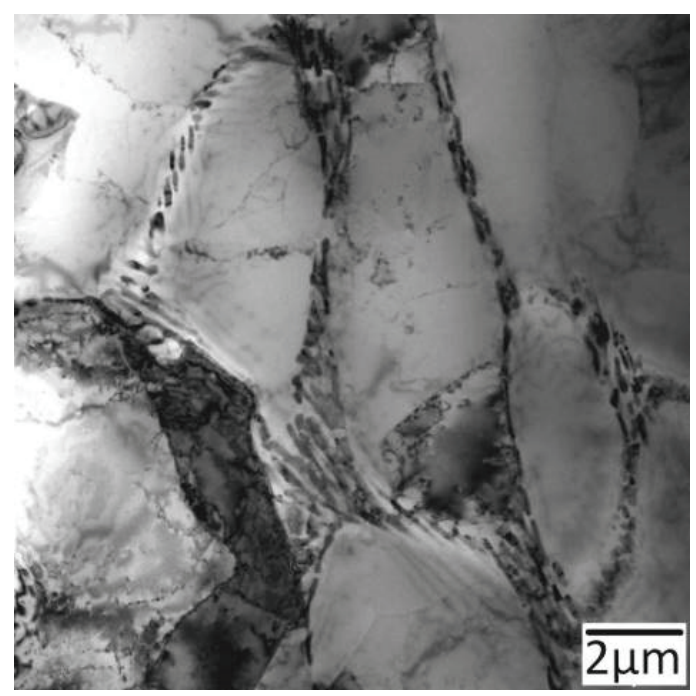

Figure 2 Microstructure of the 8006 alloy in the as cast state

Particles do not exhibit any changes during annealing up to $300^{\circ} \mathrm{C}$. Only dislocation recovery and formation of well-defined subgrains was observed (Figure $3 \mathrm{a}$ ). This process is in accordance with similar observations [15] responsible for the local minimum on the resistivity curve at $270{ }^{\circ} \mathrm{C}$. No significant changes have been observed even at $450^{\circ} \mathrm{C}$ (Figure $3 \mathrm{~b}$ ), although a pronounced minimum appeared on the resistivity curve. This discrepancy might be related to a difference in heating rates used in the resistometric and TEM measurements. Due to a higher effective heating rate used during the in-situ TEM experiment some diffusion controlled processes could be shifted to higher temperatures.
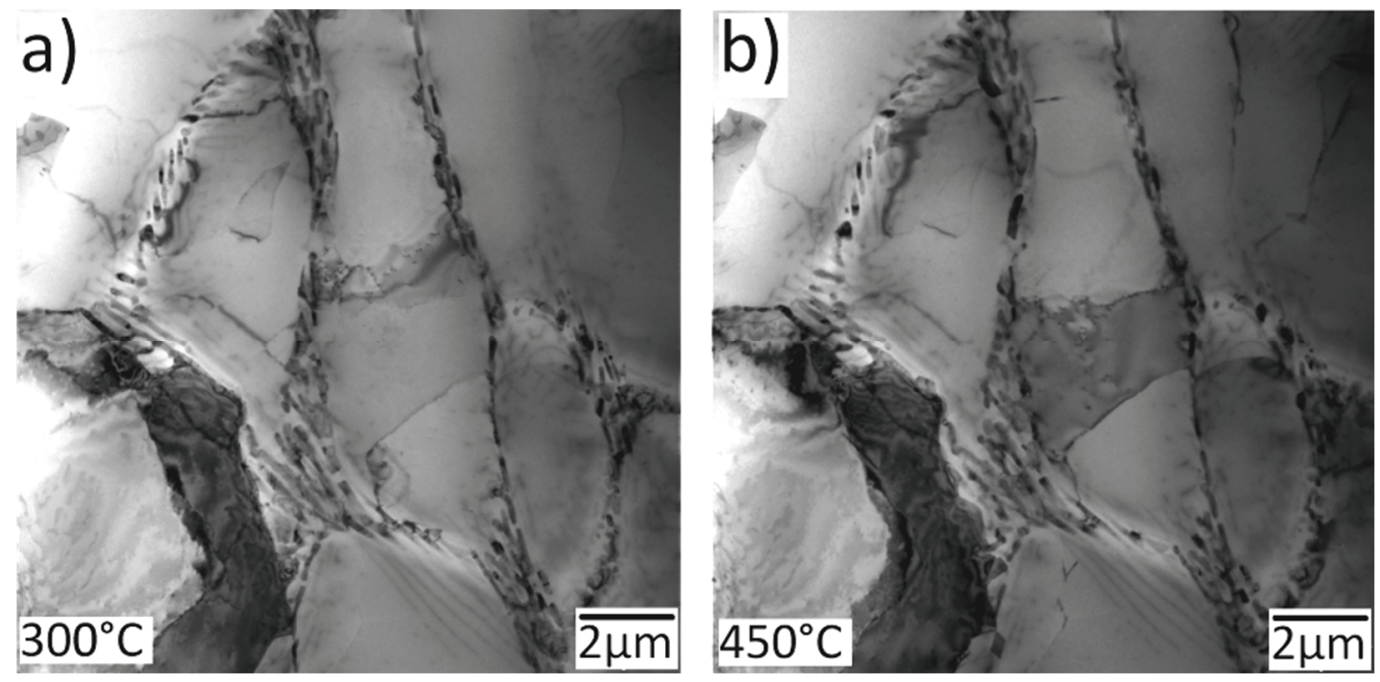

Figure 3 Microstructure of the 8006 alloy annealed at $300{ }^{\circ} \mathrm{C}$ and $450{ }^{\circ} \mathrm{C}$

At higher annealing temperatures, most noticeably at $500{ }^{\circ} \mathrm{C}$, spheroidization of the originally elongated particles begins along with a formation and growth of new particles (Figure $\mathbf{4} \mathbf{b}$ ). The spheroidization of original particles continues with increasing temperature and finally nearly all original particles dissolve enabling the formation and growth of larger plate shaped particles (Figures $4 \mathbf{c}, \mathbf{d}$ ). These platelet particles grow preferably along the original grain boundaries and nearly no formation inside the interiors of grains was observed. 


\section{ME'TAL
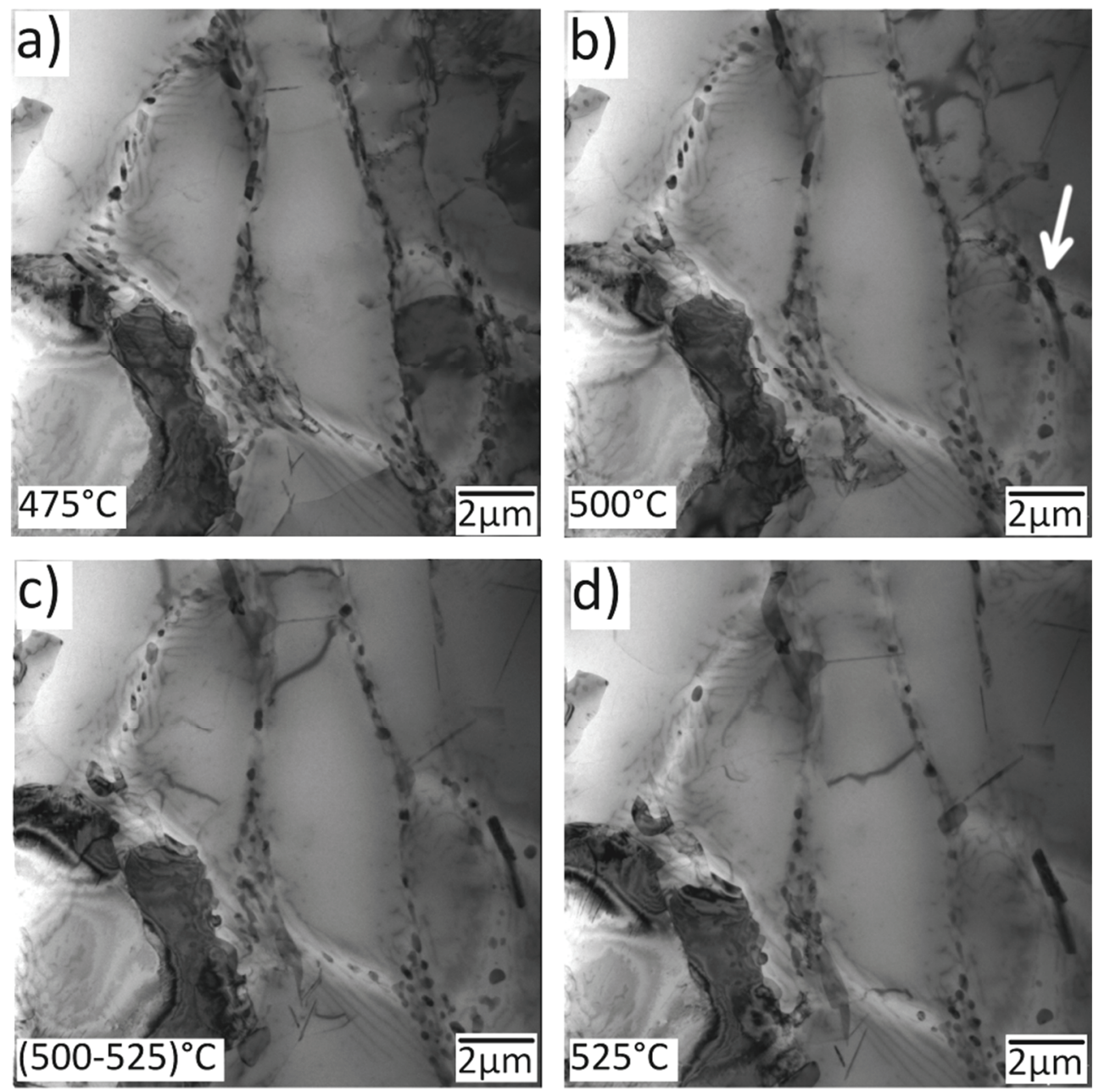

Figure 4 Microstructure of the 8006 alloy annealed up to indicated temperatures. Particle growing fast at $500{ }^{\circ} \mathrm{C}$ is highlighted by a white arrow.

Further dissolution and growth occurs fairly rapidly. Almost all the original particles dissolve at $550{ }^{\circ} \mathrm{C}$ (Figures $\mathbf{5} \mathbf{a}, \mathbf{b}$ ) and none of them remain in the observed area. The number of newly formed particles is very low and they are much coarser than the original ones.
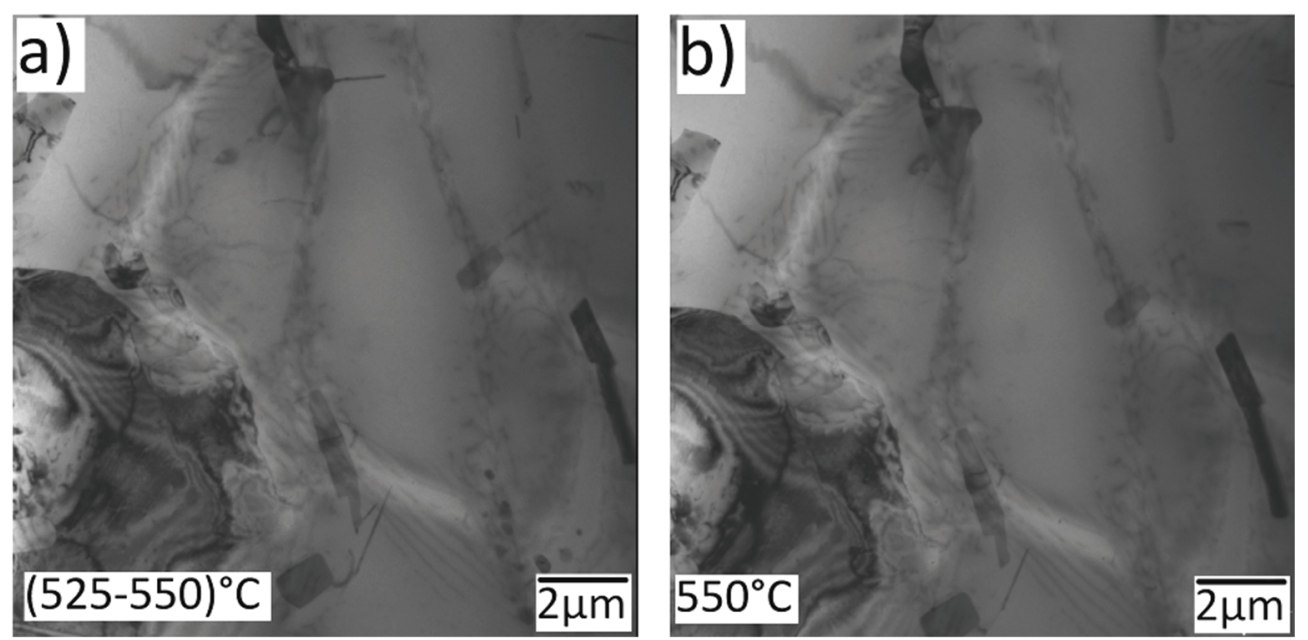

Figure 5 Microstructure of the 8006 alloy annealed up to $550^{\circ} \mathrm{C}$ 
While none of the original particles remain in the observed area a wider view of the specimen (Figure 6) shows a small fraction of them. Compared to the grown platelet particles their volume fraction in the material is negligible. Newly formed particles have various morphologies and sizes with several of them being very thin and up to $5 \mu \mathrm{m}$ long. Nearly all of them were found on grain boundaries. The original grain structure remains intact even at these high temperatures. While the resistometry measurement was done up to $600{ }^{\circ} \mathrm{C}$, the insitu TEM observations were stopped at $550^{\circ} \mathrm{C}$ because a degradation of thin foil generally occurs above this temperature.

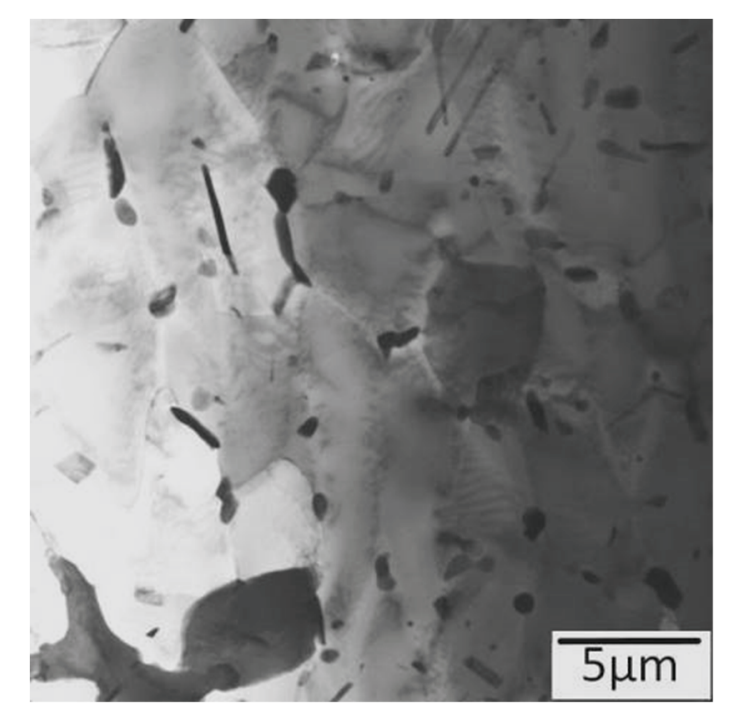

Figure $6 \mathrm{~A}$ wide view of the 8006 alloys microstructure after annealing up to $550{ }^{\circ} \mathrm{C}$

As has been already mentioned, observed phase transformations do not fit exactly with the position of local minima in the resistivity curve. Beside a different heating schema the role of thin foil and surface diffusion could have a significant influence on the kinetics of observed processes. Therefore results should be carefully analyzed. Most probably a massive depletion of the matrix from Mn, Si and residual Fe occurs above $4500^{\circ} \mathrm{C}$ causing morphological changes of original particles and significant changes of resistivity. Their dissolution and transition of alloying elements into newly formed particles have significantly lower impact on resistivity changes.

\section{CONCLUSION}

TEM observations have shown that the microstructure of the 8006 alloy in the as cast state consists of eutectic colonies of elongated particles. Spheroidization of these particles and growth of newly formed ones occurs at temperatures above $475^{\circ} \mathrm{C}$. At higher annealing temperatures the spheroidized particles dissolve and the new plate shaped particles became coarser. At $550{ }^{\circ} \mathrm{C}$ almost none of the original particles remain and the microstructure contains mainly large platelet particles situated at the boundaries of the original grains. Crystallographic identification of initial and final particles is in progress.

\section{ACKNOWLEDGEMENTS}

The financial support of the GAUK project number 704119 is highly acknowledged.

\section{REFERENCES}

[1] KERRY, J. Aluminium food packaging. Packaging technology: Fundamentals, Materials and Processes. 2012. pp. 163-177. 
[2] ZAMIN, M. The role of Mn in the corrosion behavior of Al-Mn Alloys. Corrosion. 1981. vol. 37, no. 11, pp. 627-632.

[3] KUIJPERS, N.C.W., KOOL, W.H., KOENIS, P.T.G., et al. Assessment of different techniques for quantification of $\alpha-\mathrm{Al}(\mathrm{FeMn}) \mathrm{Si}$ and $\beta$-AlFeSi intermetallics in AA 6xxx alloys. Materials Characterization. 2002. vol. 49, iss. 5, pp. 409-420.

[4] KIM, H. Y., PARK, T. Y., HAN, S.W. and LEE H. M. Effects of Mn on the crystal structure of $\alpha-A l(M n, F e) S i$ particles in A356 alloys. Journal of Crystal Growth. 2006. vol. 291, iss. 1, pp. 207-211.

[5] LI, Y.J., MUGGERUD, A.M.F., OLSEN, A. and FURU, T. Precipitation of partially coherent $\alpha-\mathrm{Al}(\mathrm{Mn}, \mathrm{Fe}) \mathrm{Si}$ dispersoids and their strengthening effect in AA 3003 alloy. Acta Materialia. 2012. vol. 60, iss. 3, pp. 1004-1014.

[6] KIM, D.H. and CANTOR, B. Structure and decomposition behaviour of rapidly solidified Al-Fe alloys. Journal of Materials science. 1994. vol. 29, iss. 11, pp. 2884-2892.

[7] LIANG, D. and JONES, $\mathrm{H}$. Morphologies of primary $\mathrm{Al}_{3} \mathrm{Fe}$ in Bridgman solidification and TIG weld traversing of hypereutectic AIFe alloys. Materials Science and Enginering: A. 1993. vol. 173, iss. 1-2, pp. 109-114.

[8] HAN, Y., CHUNYAN, B. et al. Alignment behaviour of primary $\mathrm{Al}_{3} \mathrm{Fe}$ phase in Al-Fe alloy under a high magnetic field. Materials Letters. 2007. vol. 61, iss. 6-7, pp. 983-986.

[9] LEE, Y., KIM, H. and CHO, J. Effect of Casting Parameters on Roll Separation Force during Twin Roll Casting. Procedia Engineering. 2014. vol. 81, pp. 1547-1552.

[10] CHEN, S. and CHEN, J. Simulation of microstructures in solidification of aluminium twin-roll casting. Transaction of Nonferrous Metals Society of China. 2012. vol. 22, iss. 6, pp. 1452-1456.

[11] LEE, Y., KIM, H. and CHO, J. Process parameters and roll separation force in horizontal twin roll casting of aluminum alloys. Journal of Materials Processing Technology. 2015. vol. 218, pp. 45-56.

[12] BIROL, Y. Response to annealing treatment of a twin-roll cast thin AlFeMnSi strip. Journal of Materials Processing Technology. 2009. vol. 209, iss. 1, pp. 506-510.

[13] KELES, O. and DUNDAR, M. Aluminium foil: Its typical quality problems and their causes. Journal of Materials Processing Technology. 2007. vol. 186, iss. 1-3, pp. 125-137.

[14] KITTEL, Ch. Introduction to solid state physics. 8th ed. Wiley, 2005. p. 598.

[15] POKOVÁ, M. Microstructure of non-equiblirium Al-Mn based solid solutions. (Thesis). Prague: Charles University, Department of Physics of Materials. 2012. 